\title{
A RARE CASE REPORT: CONGENITAL HYPOFIBRINOGENAEMIA - A NEWBORN INFANT WITH CORD BLEEDING
}

\author{
Suryakant Yashwant Ingale1, Prashant Popatlal Shah", Raghunandan Reddy Bheem Reddy³, Pulkit Devrajbhai Sheta", \\ Pratik Kamalaprasad Yadav 5
}

${ }_{1}^{1}$ Associate Professor, Department of Paediatrics, Krishna Institute of Medical Sciences, Karad.

${ }^{2}$ Assistant Professor, Department of Paediatrics, Krishna Institute of Medical Sciences, Karad.

${ }^{3}$ Resident, Department of Paediatrics, Krishna Institute of Medical Sciences, Karad.

${ }^{4}$ Resident, Department of Paediatrics, Krishna Institute of Medical Sciences, Karad.

${ }^{5}$ Resident, Department of Paediatrics, Krishna Institute of Medical Sciences, Karad.

\section{ABSTRACT}

The genetic disorders causing decreased fibrinogen synthesis may be caused by heterozygous (hypofibrinogenaemia) or homozygous (afibrinogenaemia) deficiency. ${ }^{1}$ The consequences of the disorders are gastrointestinal bleeding, cord bleeding, ecchymoses, subcutaneous haematomas and haemarthroses especially due to traumatic delivery in the neonatal period. ${ }^{2}$ Laboratory evaluation of the patient with hypofibrinogenaemia reveals prolongation of thrombin time, partial thromboplastin time, prothrombin time and decreased fibrinogen level. We report a 6-day-old, congenital hypofibrinogenaemia case with cord bleeding.

\section{KEYWORDS}

Congenital Hypofibrinogenaemia, Cord Bleeding, Newborn.

HOW TO CITE THIS ARTICLE: Ingale SY, Shah PP, Reddy RRB, et al. A rare case report: Congenital hypofibrinogenaemia - A newborn infant with cord bleeding. J. Evolution Med. Dent. Sci. 2016;5(81):6083-6084, DOI: 10.14260/jemds/2016/1374

\section{INTRODUCTION}

Coagulation system of newborn infant differs from older children and adults in terms of many characteristics and it also changes with gestational age. In term babies, acquired bleeding disorders are more frequent than genetic congenital disorders. Congenital hypofibrinogenaemia is a very rare heterozygous deficiency causing decreased fibrinogen synthesis. ${ }^{3,4}$ We describe a newborn infant with cord bleeding, clinical and laboratory features of hypofibrinogenaemia.

\section{CASE REPORT}

A 6-day-old newborn infant was admitted to our hospital for evaluation of cord bleeding. She was healthy for the first five days and developed massive cord bleeding on the sixth day. The patient was the product of a non-consanguineous marriage. She was born to a healthy mother gravida 2, para 1. Gravid 1 was a female term baby and expired due to unknown reason, was not investigated.

On admission, she was afebrile, blood pressure of $45 / 28$ $\mathrm{mmHg}$ and a regular heart rate of 160 per minute. Her weight was $2350 \mathrm{~g}$ (75-90 percentile), height $50 \mathrm{~cm}$ ( $>90$ percentile). Physical examination revealed a pale skin, cord bleeding and palpable liver $1 \mathrm{~cm}$ below the ribs.

\section{INVESTIGATION}

Laboratory investigation showed haemoglobin of $19.5 \mathrm{~g} / \mathrm{dL}$, leukocyte count $19,200 / \mathrm{mm}^{3}$, platelet count $461,000 / \mathrm{mm}^{3}$. A peripheral blood smear was normal. Bleeding time was 5 minutes (by Ivy method), clotting time was longer than 10 minutes, prothrombin time (PT) was $>180$ seconds, activated

Financial or Other, Competing Interest: None.

Submission 01-09-2016, Peer Review 25-09-2016,

Acceptance 01-10-2016, Published 10-10-2016.

Corresponding Author:

Dr. Pulkit Devrajbhai Sheta,

Room No. 106, IHR Hostel,

Krishna Institute of Medical Sciences,

Malkapur, Karad-415110.

E-mail: pulkitsheta@gmail.com

DOI: $10.14260 /$ jemds/2016/1374 partial thromboplastin time (PTT) was $>180$ seconds and plasma fibrinogen was $<60 \mathrm{mg} / \mathrm{dL} .5,6$ Bilirubin levels 21.7 -day 6, 15.6 day-7, 10.1 day-8. Blood urea, electrolytes, hepatic enzymes, CRP were within the normal limits.

\section{TREATMENT}

Fresh frozen plasma transfusion and Inj. Vitamin K. Fresh plasma were transfused and bleeding stopped. ${ }^{7}$ On the next day after admission, PT was 25 seconds, PTT was 30 seconds and. After one week, while PT was 21 seconds and PTT was 36 seconds; plasma fibrinogen level was $<60 \mathrm{mg} / \mathrm{dL}$. Levels of the parents' plasma fibrinogen were normal.

She was discharged on the tenth day of hospitalisation and the parents were warned that it is a genetic disorder and there is recurrence risk in their new babies. One month later, plasma fibrinogen level was again $<60 \mathrm{mg} / \mathrm{dL} .{ }^{8}$ These findings suggest congenital hypofibrinogenaemia. She is now three months old and observed as an outpatient.

\section{DISCUSSION}

Evaluating a newborn baby with bleeding is different from older children and must include a careful history of family bleeding, perinatal period, maternal illnesses (Especially for infection), neonatal and maternal drug administration and vitamin $\mathrm{K}$ administration at birth.

Observations on physical examination such as localised or diffuse bleeding, healthy or sick appearance of the baby is very important for the classification of haemorrhagic diseases. Infants appear very sick if there is disseminated intravascular coagulation (DIC) and bleeding is diffuse from several sites. Infants with isolated platelet disorders, vitamin $\mathrm{K}$ deficiency or inherited coagulation defects generally seem healthy.

Severe congenital factor commonly present with bleeding from cord, from mucous membranes, peripheral blood sampling sites, after circumcision and into the subcutaneous tissue and the scalp. Cord was the primary bleeding site in our patient and as there is a history of death of a sibling we think it is a congenital coagulation defect. As the baby appeared well, we did not think DIC or infection. 
Laboratory evaluation revealed decreased plasma fibrinogen level. Although the plasma fibrinogen level increased after replacement with fresh plasma in three days, one month later it was again low and we thought it to be a congenital fibrinogen deficiency.

Fibrinogen deficiency is a rare inherited coagulation defect. In Medline research including 62 publications, seven of 226 babies with congenital coagulation defect were found to have fibrinogen deficiency. Five of them had cord bleeding, one with haematoma and two were following circumcision.

Fibrinogen deficiency may be as hypofibrinogenaemia or afibrinogenaemia. Plasma fibrinogen normal level is 150-400 $\mathrm{mg} / \mathrm{dL}$. In afibrinogenaemia, trace amount of fibrinogen, less than $5 \mathrm{mg} / \mathrm{dL}$, can be detected. The fibrinogen level was $<60$ $\mathrm{mg} / \mathrm{dL}$ in this case and it is thought to be hypofibrinogenaemia.

This disorder is transmitted by an autosomal inheritance and gene is located on chromosome 4(q26-q28). Familial inheritance is also reported.

Bleeding can be treated with fibrinogen concentrate, cryoprecipitate or fresh frozen plasma replacement. Half-life of fibrinogen is approximately 3-5 days and minimum haemostatic level is $50-100 \mathrm{mg} / \mathrm{dL}$; for this reason, the dosage should be given to reach this level.

In conclusion, we report a rare genetic disorder, congenital hypofibrinogenaemia and should be remembered in newborn infants with cord bleeding.

\section{REFERENCES}

1. Leeners JV, Mossakowski J, Kayser S. Case report of congenital afibrinogenemia. Klin Pediatr 1995;207(1):345.

2. Al-Mondhiry H, Ehman WC. Congenital afibrinogenemia. Am J Hematol 1994;46(4):343-7.

3. Mammen EF. Fibrinogen abnormalities. Semin Thromb Hemost 1988;9:1-6.

4. Khalid F, Taumi NH, Bouguerra F. Genetics study of congenital afibrinogenemia: review of 12 cases. Ann Pediatr 1991;38(7):461-7.

5. Ehman WC, al-Mondhiry H. Congenital afibrinogenemia and splenic rupture. Am J Med 1994;96(1):92-4.

6. Corrigan JJ. Phase III disorders: hemorrhagic and thrombotic diseases. In: Berman RE, Kliegman RM, Arvin $A M$, et al. eds. Nelson textbook of paediatrics. $15^{\text {th }}$ edn. United States of America: WB Saunders Company 1996:1428-9.

7. Rodriguez RC, Buchnar GR, Clanton MS. Prophylactic cryoprecipitate in congenital afibrinogenemia. Clin Pediatric 1988;27(11):543-5.

8. Teitel JM. Unexpected bleeding disorders: algorithm for approach to therapy. Clin Lab Haem 2000;22(Suppl 1): 26-9. 